\title{
THE STUDY OF THE INFLUENCE OF MODEL MEAT SYSTEMS ON THE ALLERGIC IMMUNE RESPONSE IN VIVO
}

\section{ИЗУЧЕНИЕ ВЛИЯНИЯ МОДЕЛЬНЫХ МЯСНЫХ СИСТЕМ НА АЛЛЕРГИЧЕСКУЮ РЕАКЦИЮ ИММУНИТЕТА IN VIVO}

Dydykin A.S., Minaev M.Y., Tolmacheva G.S., Musatova A.A.

The V.M. Gorbatov All-Russian Meat Research Institute, Moscow, Russia

Ключевые слова: пищевая аллергия, лабораторные животные, сывороточный альбумин, ферменты, гематологические показатели, иммуноферментный анализ.

\section{Аннотация}

В данной статье представлены результаты изучения влияния гомогенных мясных модельных систем, полученных с применением ферментного препарата грибной протеазы и микробиологической стартовой культуры Lactobacillus plantarum, на аллергическую реакиию специфического иммунитета in vivo. По результатам исследований установлено, что опьтные продукты не оказывают негативного влияния на клиническое состояние лабораторных животных. На протяжении эксперимента динамика изменения массы тела животных всех групп была положительной, при введении опьтных образцов в рацион, отмечены меньший прирост веса крыс и меньшие значения привесов животных в коние эксперимента (у крыс 1 группь 14,0\%, 2 группь - 15,9\%, у животных 3 группь - 20,2\%). Возможно это связано с адаптационными процессами, происходяшими в ответ на введение в рацион мясных систем, что подтверждает нивелирование ежесуточного привеса опытных и интактных животных начиная с 16-х суток эксперимента. По результатам общего клинического анализа крови животных, потреблявших опытные продукты, выявлено увеличение тейкоцитов и лимбоцитов до $18 \%$, гранулоцитов до $35 \%$ и моноцитов до 8\%, кониентрации гемоглобина, уровня гематокрита и средней концентрации гемоглобина в эритроиите свыше $3 \%$, иирины распределения эритроизитов и среднего объема эритроцита до $2 \%$ по сравнению с интактными животными. Соотночение этих данных с анализом иммуноферментных показателей сыворотки крови опытных животных (гистамин и иммуноглобулин Е) позволило высказать предположение об экспрессии реагиновых антител и взаимодействии на поверхности базофилов и тучных клеток, приводящих к дегрануляции и высвобождению (увеличению) гистамина, как вазоактивного фактора, на $40 \%$ в сравнении с интактной группой.

Общий вывод исследований указывает на то, что опытные мясные модельные системы могут вызывать активацию специфических иммунных реакиий у лабораторных животных. Возможно, это связано с образованием под действием протеаз большего количества сложноусваеваемых полипептидных и пептидных соединений, вызывающих местные адаптационные реакции.

\section{Введение}

На сегодняшний день проблемы аллергии составляют значительную часть среди заболеваний неинфекционного происхождения. В структуре данной
Keywords: food allergy, laboratory animals, serum albumin, enzymes, hematological parameters, enzyme-linked immunosorbent assay.

\section{Abstract}

This article presents the results of studying the effect of homogeneous model meat systems produced using enzyme preparation containing fungal protease and microbiological starter culture of Lactobacillus plantarum on the allergic reactions within specific immunity in vivo. According to the results, it is established that experimental products have no negative effect on the clinical parameters of laboratory animals. During the experiment, with the introduction of experimental products into diet, the dynamics of body weight changes in all groups of animals was positive. At the end of the experiment, there were smaller increase in the weight of rats and lower values of weight gain (Group 1-14.0\%, Group 2-15.9\%, Group 3-20.2\%). This is possibly due to the adaptation processes occurring in response to introduction of meat systems into the diet, which confirms the leveling of the daily weight gain of experimental and intact animals since the 16th day of the experiment.

According to the results of clinical blood analysis of the animals consuming experimental products, an increase is detected in leukocytes and lymphocytes by up to $18 \%$; in granulocytes by up to $35 \%$; and in monocytes by up to $8 \%$; in hemoglobin concentration, hematocrit and mean corpuscular hemoglobin concentration by more than $3 \%$; in red cell distribution width and mean corpuscular volume by up to $2 \%$, in comparison with intact animals. The correlation of these data with ELISA parameters for serum of experimental animals (histamine and immunoglobulin E) allowed to suggest the expression of reaginic antibodies and interaction on the surface of basophils and mast cells, which led to the degranulation and release (increase) of histamine, as a vasoactive factor, by $40 \%$ compared with intact animals.

The overall conclusion of the studies is that experimental model meat systems may trigger the activation of specific immune responses in laboratory animals. This is possibly due to proteasemediated formation of greater amount of indigestible polypeptides and peptides that invoke local adaptation responses.

\section{Introduction}

To date, allergy problems account for a significant proportion of non-infectious diseases. Among them, food allergy has leading positions. This pathology is especially 
патологии пищевая аллергия занимает лидирующие позиции. Особое значение данная патология имеет для детей раннего возраста, так как в силу не зрелости ферментных систем желудочно-кишечного тракта организм ребенка не всегда способен расщеплять пищевые субстраты до полуэлементных и элементных нутриентов, которые безопасно включаются в метаболизм [1]. У большинства детей, особенно проживающих в городах, хотя бы раз была аллергическая реакция на пищевой ингредиент, макро- или микрокомпонент, причем у $30 \%$ детей аллергические проблемы приобретают хронический характер.

Одним из законодательных (нормативных) документов, подтверждающих актуальность и распространённость пищевой аллергии, является принятый Технический регламент Таможенного союза ТP ТС 022/2011 «Пищевая продукция в части ее маркировки». Статья 4 «Требования к маркировке пищевой продукции» данного документа устанавливает требования, обязывающие производителя указывать в составе пищевой продукции компоненты (в том числе пищевые добавки, ароматизаторы), биологически активные добавки, употребление которых может вызвать аллергические реакции или противопоказано при отдельных видах заболеваний. Причем количество потенциальных аллергенов должно указываться независимо от их количества.

Согласно ТР ТС 022/2011, к наиболее распространенным компонентам, употребление которых может вызвать аллергические реакции или противопоказано при отдельных видах заболеваний, относятся:

- $\quad$ арахис и продукты его переработки;

- аспартам и аспартам-ацесульфама соль;

- горчица и продукты ее переработки;

- диоксид серы и сульфиты, если их общее содержание составляет более 10 миллиграммов на один килограмм или 10 миллиграммов на один литр в пересчете на диоксид серы;

- злаки, содержащие глютен, и продукты их переработки;

- кунжут и продукты его переработки;

- люпин и продукты его переработки;

- моллюски и продукты их переработки;

- молоко и продукты его переработки (в том числе лактоза);

- орехи и продукты их переработки;

- ракообразные и продукты их переработки;

- рыба и продукты ее переработки (кроме рыбного желатина, используемого в качестве основы в препаратах, содержащих витамины и каротиноиды);

- сельдерей и продукты его переработки;

- соя и продукты ее переработки;

- яйца и продукты их переработки.

Конечно, данный перечень не является исчерпывающим и как правильно отмечено - это наиболее распространенные компоненты, так как у детей, important for young children, because child's body is not always able to split food substrates into safely metabolized semi-elemental and elemental nutrients [1], due to immaturity of the enzyme systems of gastrointestinal tract. Most children, especially those who live in cities, had at least one allergic reaction to food ingredient, macro- or micro-component, and in $30 \%$ of children allergic problems become chronic.

One of the regulative documents confirming relevance and prevalence of food allergy is the adopted Technical Regulations of the Customs Union TR TS 022/2011 «Food products in terms of its labeling.» Article 4 «Requirements for labeling of food products» of this document establishes requirements for manufacturer to indicate components of food products (including food additives, flavoring agents), bioactive additives, which consumption may cause allergic reactions or is contraindicated in certain types of diseases. Moreover, the number of potential allergens should be indicated regardless of their number.

According to TR TS 022/2011, the most common components, which consumption may cause allergic reactions or is contraindicated in certain types of diseases, include the following:

- peanuts and related processed products;

- aspartame and aspartame-acesulfame salt;

- mustard and related processed products;

- sulfur dioxide and sulfites, if their total content is greater than 10 milligrams per kilogram or 10 milligrams per liter based on sulfur dioxide;

- cereals containing gluten and related processed products;

- sesame and related processed products;

- lupine and related processed products;

- shellfish and related processed products;

- milk and related processed products (including lactose);

- nuts and related processed products;

- crustaceans and related processed products;

- fish and related processed products (excluding fish gelatin used as a base in preparations containing vitamins and carotenoids);

- celery and related processed products;

- soybeans and related processed products;

- eggs and related processed products.

Of course, this list is not complete, and as it is correctly noted, these are the most common components, since in 
особенно раннего возраста, аллергические реакции могут вызывать и другие пищевые источники, в том числе мясо [2]. В мясе животных имеется два основных потенциальных аллергена - сывороточный альбумин и гамма-глобулин [3]. При острой чувствительности на эти вещества, у детей может наблюдается нарушение функционирования желудочно-кишечного тракта (рвота, понос, расстройство желудка), выступить сыпь, ощущаться зуд на разных участках тела, возникнуть аллергический ринит (насморк) и даже приступы удушья (анафилаксии) $[4,5]$. Сывороточный альбумин - наиболее широко изученный и наиболее распространенный протеин крови (70\% от общего протеинового состава). Его концентрация в плазме составляет 35-55 мг/мл. Бычий сывороточный альбумин (БСА) представляет собой глобулу в форме сплюснутого эллипсоида вращения с полуосями 17 на 42 ангстрем, состоящую из 607 аминокислотных остатков. БСА обладает достаточно сложной пространственной структурой, образующей три домена, каждый из которых, в свою очередь подразделяется на два поддомена (А-В и С). Молекулярная масса БСА 69 кДа.

Пищевой аллергией, как правило, заболевает 15$40 \%$ детей, начиная с раннего возраста. При этом в последние годы значительно увеличился процент детей, страдающих пищевой аллергией к коровьему молоку, а также к говяжьему мясу, так как эти продукты имеют антигенное сродство входящих в их состав белков [6]. Ограничение или исключение этих продуктов из питания детей, создает большие трудности в обеспечении физиологической потребности в белке животного происхождения, что чрезвычайно важно для их нормального роста и развития.

В связи с этим, на сегодняшний день ассортимент продуктов, обладающих пониженной аллегренностью, в основном представлен искусственными смесями на основе белков молока и сои $[7,8,9,10,11]$. Низкоаллергенные продукты на мясной основе отечественных (торговые марки «Тема», «Бабушкино лукошко», «Агуша», «Фруто-няня») и зарубежных производителей (компании «Nestlé», «Gerber», «Heinz») представлены консервами, изготовленными из различных видов мяса (конина, кролик, индейка), обладающих низким риском сенсибилизации у детей раннего возраста при их потреблении. Применение этих продуктов в диетических рационах детей, страдающих пищевой непереносимостью, свидетельствует о высокой эффективности $[12,13,14]$. Существует несколько технологических способов снижения аллергенности основных продуктов питания за счет полной или значительной элиминации сенсибилизирующих веществ:

- гидролиз - биотрансформация аллергена (получение гидролизатов молочных, растительных белков);

- тепловая обработка - варка, бланширование (производство мясных и рыбных продуктов); children, especially those of early age, allergic reactions may be caused by other food sources, including meat [2]. Animal meat contains two main potential allergens - serum albumin and gamma globulin [3]. Acute sensitivity to these substances in children may cause gastrointestinal disorders (vomiting, diarrhea, indigestion), rash, itching at different parts of the body, allergic rhinitis and even asthma attack (anaphylaxis) $[4,5]$. Serum albumin is the most widely studied and most abundant blood protein (70\% of total protein composition). Its plasma concentration is $35-55 \mathrm{mg} / \mathrm{ml}$. Bovine serum albumin (BSA) is a globule in the form of oblate spheroid with 17 semiaxes to 42 angstroms consisting of 607 amino acid residues. BSA has the complex spatial structure of three domains, each of which, in turn, is divided into two subdomains (A-B and C). The molecular weight of BSA is $\sim 69 \mathrm{kDa}$.

Food allergy, as a rule, affects $15-40 \%$ of children starting from an early age. In recent years, the percentage of children suffering from food allergy to cow's milk and beef has increased significantly, since these products have antigenic affinity for proteins in their composition [6]. Restricting or excluding these foods from the nutrition of children creates great difficulties to meet physiological need for animal protein, which is extremely important for their normal growth and development.

In this regard, the range of products with reduced allergenic potential is currently represented mainly by artificial mixtures of milk and soy proteins $[7,8,9,10,11]$. Low-allergenic meat-based products of domestic («Tioma», «Babushkino Lukoshko», «Agusha», «Fruto-Niania» trademarks) and foreign producers (Nestlé, Gerber, Heinz companies) are presented by canned food made of different meat types (horse meat, rabbit, turkey) with low risk of sensitization in small children. The use of these products in diets of children suffering from food intolerance demonstrates high efficiency $[12,13,14]$. There are several technological approaches to reduce allergenic potential of basic food products by total or significant elimination of sensitizing substances:

- hydrolysis, i.e. allergen biotransformation (obtaining hydrolysates of milk proteins and plant proteins);

- heat treatment, i.e. boiling, blanching (production of meat and fish products); 
- фильтрация - удаление аллергена (производство молочных продуктов, соков);

- сочетание способов (получение смесей на основе молочных, растительных белков).

В этой связи чрезвычайно актуальной становится задача по созданию технологии новых продуктов детского питания на основе мясного сырья, обладающего гипоаллергенными свойствами. При этом, учитывая особенности мясного сырья и технологии его переработки, перспективными являются комбинированные способы снижения аллергенности, включающие в себя ферментацию и тепловую обработку.

Таким образом, целью данной работы было изучение влияния гомогенизированных мясных продуктов, обработанных ферментными препаратом на аллергическую реакцию иммунитета лабораторных животных.

\section{Материалы и методы}

Исследование выполнено в ФГБНУ «ВНИИМП им. В.М. Горбатова» на базе Экспериментальной Клиники-лаборатории биологически активных веществ животного происхождения.

Эксперимент проведен на клинически здоровых сексуально наивных лабораторных крысах spf-категории стока Wistar, массой (348 \pm 17) г, полученных из Центра генетических ресурсов лабораторных животных Федерального исследовательского центра Института цитологии и генетики Сибирского отделения Российской академии наук (ЦГР ИЦиГ СО РАН, Новосибирск).

До проведения эксперимента животные проходили адаптацию к лабораторным условиям в течение 14 суток. На протяжении всего эксперимента крыс содержали в системе индивидуально-вентилируемых клеток (ИВК) в составе вентиляционного блока VENT II и стеллажа с клетками типа Bio.A.S. тип III (EHRET, Германия), обеспечивающей создание оптимального микроклимата в каждой отдельной клетке. Условия содержания крыс в ИВК были сходные в отношении температуры $\left(22 \pm 3^{\circ} \mathrm{C}\right)$, влажности (50-60\%), освещения 12/12 (с 6.00 до 18.00 световой день).

На протяжении эксперимента крысы потребляли полнорационный комбикорм ad libitum (АссортиментАгро, Россия) по ГОСТ Р 50258-92, сбалансированный по белку, пищевая ценность которого представлена в таблице 1.

Питьевую воду для поения лабораторных животных получали на установке водоподготовки EMD Millipore $\mathrm{RiOs}^{\mathrm{Tm}} 50$ (Merc Millipore, Германия), минерализацию осуществляли путем добавления минеральных солей для получения физиологически полноценного минерального состава (минерализация 314-382 мг/л: гидрокарбонаты - 144-180, сульфаты $<1$, хлориды - 60-76, кальций - 6, магний - 3, натрий - 50-58, калий - 50-58). Температура воды для поения составляла $10-12^{\circ} \mathrm{C}$.
- filtering, i.e. removing the allergen (production of dairy products, juices);

- combination of different methods (preparation of mixtures based on dairy and vegetable proteins).

In this context, an extremely urgent task arises in terms of creating a new technology for baby foods based on meat raw materials with hypoallergenic properties. In this case, given the characteristics of meat raw materials and processing technologies, combined approaches to reduce allergenic potential, including fermentation and heat treatment, are becoming fairly promising.

Thus, the aim of this study was to investigate the influence of homogenized meat products treated with the enzyme preparation on the allergic immune response in laboratory animals.

\section{Materials and methods}

The study was carried out by The V.M. Gorbatov All-Russian Meat Research Institute at the Experimental Clinic-Laboratory of Biologically Active Substances of Animal Origin.

The experiment was carried out on clinically healthy, sexually naive laboratory Wistar rats of spf-category with weight of $348 \pm 17 \mathrm{~g}$ obtained from the Center for Genetic Resources of Laboratory Animals in Federal Research Center of the Cytology and Genetics Institute, Siberian Branch of the Russian Academy of Sciences, Novosibirsk.

Before the experiment, the animals underwent adaptation to the laboratory conditions for 14 days. Throughout the experiment, the rats were kept in a system of individually ventilated cages (IVC) as part of the VENT II ventilation unit and Type III Bio.A.S. cage rack (EHRET, Germany) ensuring optimal microclimate in each individual cage. The conditions of rats in IVC were similar as for temperature $\left(22 \pm 3^{\circ} \mathrm{C}\right)$, humidity $(50-60 \%)$, illumination $12 / 12$ (6.00 to 18.00 light day).

Throughout the experiment, rats were fed ad libitum with all-in-one mixed feed balanced by protein (Assortiment-Agro, Russia) according to GOST R 50258-92. Nutritional value of mixed feed is presented in Table 1.

Drinking water for laboratory animals was obtained at EMD Millipore RiOs ${ }^{\text {Tix }} 50$ water treatment plant (Merc Millipore, Germany). Mineralization was carried out by adding mineral salts to obtain physiologically optimal mineral composition (mineralization 314-382 mg/L: hydrogen carbonates $-144-180$, sulfates $-<1$, chlorides 60-76, calcium -6 , magnesium -3 , sodium $-50-58$, potassium - 50-58). Drinking water temperature was $10-12{ }^{\circ} \mathrm{C}$. 
Table 1. Nutritional value of mixed feed | Табл. 1. Пищевая ценность комбикорма

\section{Parameter | Наименование показателя}

Contents | Содержание

Energy, not less than, kkal/100 g | Обменная энергия не менее, ккал/100 г

Crude protein, not less than, \% | Сырой протеин не менее, \% 300

Crude fat, not less than, \% | Сырой жир не менее, \%

Crude fiber, not more than, \% | Сырая клетчатка не более, \%

Ash, not more than, \% | Зола не более, \%

Calcium, not less than, \% | Кальций не менее, \%

Phosphorus, not less than, \% | Фосфор не менее, \%

Lysine, not less than, \% based on dry matter| Лизин не менее, \% на а.с.в.

Methionine-cystine, not less than, \% based on dry matter | Метионин-цистин не менее, \% на а.с.в.

Vitamin A 1000, IU/kg | Витамин A 1000, ME/кг

Vitamin E, mg/kg | Витамин E, мг/кг

Vitamin D3, 1000 IU/kg | Витамин Д3, 1000 МЕ/кГ

K3, mg/kg | К3, мг|кг

B1, mg/kg | В1, мГ \кГ

B2, $\mathrm{mg} / \mathrm{kg}|\mathrm{B} 2, \mathbf{M \Gamma}| \mathbf{~}$

B3, mg/kg | В3, мг|кг

B4, mg/kg | B4, мг \кГ

B5, mg/kg | B5, мг \кГ

B6, mg/kg | B6, мг \кг

$\mathrm{Bc}, \mathrm{mg} / \mathrm{kg} \mid \mathrm{Bc}, \mathbf{M \Gamma} \backslash \mathbf{~ К ~}$

B12, mg/kg | B12, мГ|КГ

$\mathrm{C}, \mathrm{mg} / \mathrm{kg}|\mathrm{C}, \mathbf{M \Gamma}| \mathrm{K \Gamma}$

$\mathrm{H}, \mathbf{m g} / \mathbf{k g}|\mathbf{H}, \mathbf{M \Gamma}| \mathbf{K \Gamma}$

Manganese, $\mathrm{mg} / \mathrm{kg}$ | Марганец, мг $\mid к г$

Zinc, mg/kg | Цинк, мг|кг

Iron, mg/kg | Железо, мг\кг

Copper, mg/kg | Медь, мг $\mid к г$

Iodine, $\mathrm{mg} / \mathrm{kg} \mid$ Иод, мг|кг

Cobalt, mg/kg| Кобальт, мг|кг

Selenium, mg/kg | Селен, мг|кг

Технологическая схема изготовления модельных мясных продуктов представлена на рис. 1. Пунктирными стрелками показан процесс изготовления контрольных образцов мясных продуктов.

После адаптационного периода, животных индивидуально маркировали и распределяли на группы случайным образом:

1 группа - контрольные животные, потреблявшие контрольные образцы мясных продуктов;

2 группа - животные, потреблявшие на протяжении эксперимента опытные образцы мясных продуктов, обработанных ферментным препаратом и молочнокислыми бактериями;

3 группа - интактные животные, потреблявшие на протяжении эксперимента комбикорм.

Исследуемые модельные мясные продукты вводили в количестве $50 \%$ от общего белка рациона, рационы крыс 1-3 групп были сбалансированы по белку.

20

20

5

4

7

0.9

0.6

1.2

0.7

45

202

2.48

18

76

32

126

2700

129

28

64

0.13

113

0.54

91

86

162

14

1.9

1.8

0.27

The technological flow chart for model meat product manufacturing is shown in Fig. 1. The dashed arrows indicate the process of control samples production.

After the adaptation period, the animals were individually labeled and randomly assigned to different groups:

Group 1 - control animals consumed control samples of meat products;

Group 2 - animals consumed experimental meat products treated with enzyme preparation and lactic acid bacteria;

Group 3 - intact animals consumed mixed feed.

The studied model meat products were introduced in the amount of $50 \%$ of total protein in the diet; rat diets in all groups were well-balanced by protein. 


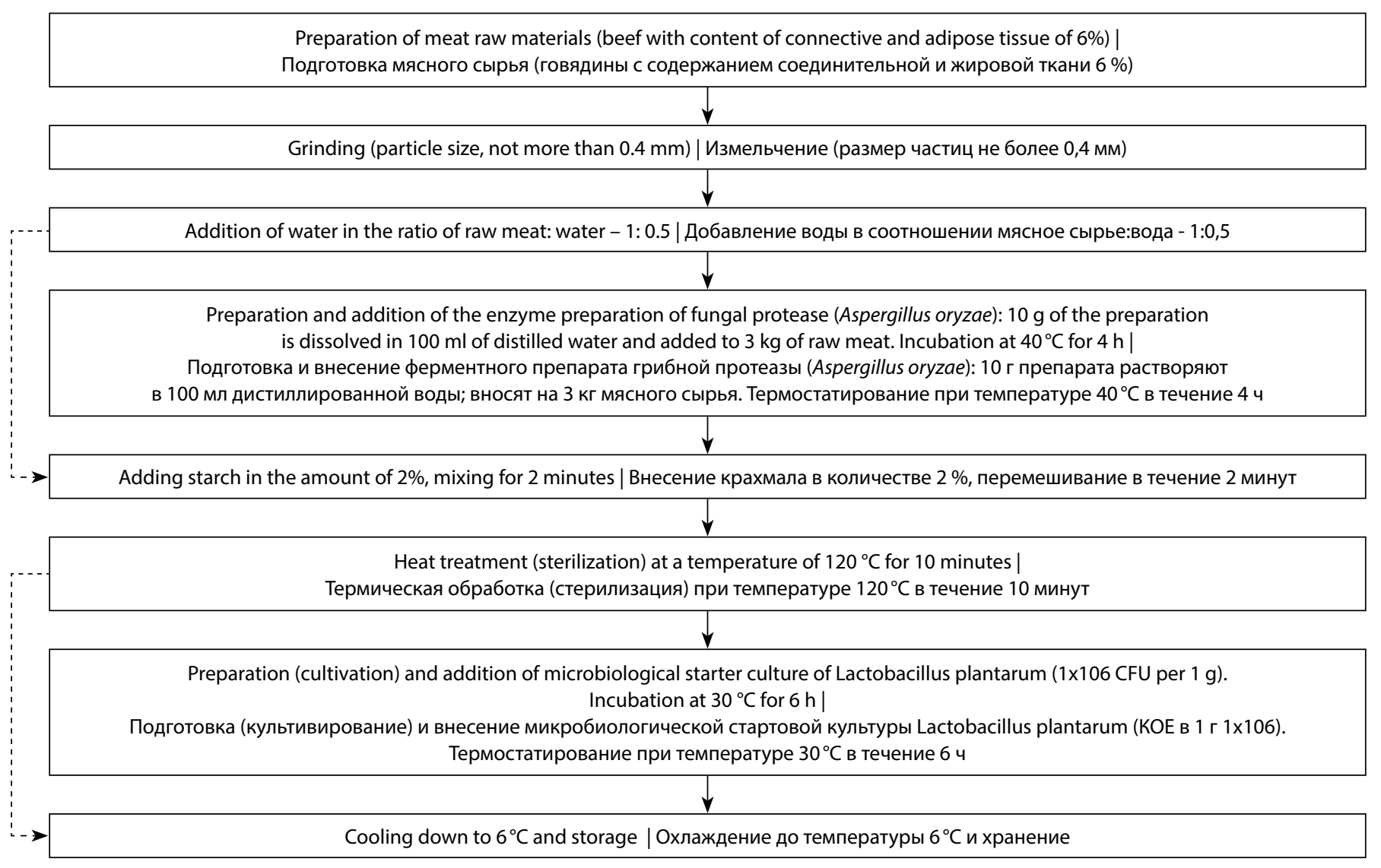

Figure 1. Technological flow chart for the production of model meat systems

Рис. 1. Технологическая схема изготовления модельных мясных продуктов

Эксперимент проводился в течение 28 суток. Наблюдение за животными осуществляли ежедневно в течение всего эксперимента. Регистрировали клинический статус и поведение животных, состояние нервномышечных функций, шерстного покрова, поедание корма, потребление воды. До начала исследования и через каждые 3-е суток исследования проводили взвешивание животных на электронных лабораторных весах (Ohaus, США) для составления диаграммы привесов.

По окончании эксперимента, животных усыпляли в камере для эвтаназии (VetTech, Великобритания) с помощью углекислого газа, после чего проводили отбор крови и общую аутопсию.

Общее клиническое исследование проб крови проводили на автоматическом ветеринарном гематологическом анализаторе Abacusjuniorvet 2.7 (Diatron Messtechnik $\mathrm{GmbH}$, Австрия), используя наборы реактивов компании Diatron. В крови животных определяли 14 показателей: лейкоциты (WBC); лимфоциты (LYM); содержание смеси моноцитов, эозинофилов, базофилов и незрелых клеток (MID); гранулоциты (GRA); лимфоциты (LY); миелоциты (MI); относительное содержание гранулоцитов (GR); эритроциты (RBC); гемоглобин (HGB); гематокрит (HCT); средний объем эритроцита (MCV); среднее содержание гемоглобина в эритроците $(\mathrm{MCH})$; среднюю концентрацию гемоглобина в эритроцитах (MCHC); ширину распределения эритроцитов (RDWc).

Иммуноферментные показатели (иммуноглобулин E, гистамин) определяли на анализаторе Immunochem
The experiment lasted 28 days. Observation of the animals was carried out daily throughout the experiment. Clinical parameters and behavior of animals, neuromuscular functions, hair condition, feed intake, and water consumption were recorded. Prior to the study and every 3 days of the study, animals were weighed on an electronic laboratory scale (Ohaus, USA) to plot weight gain chart.

At the end of the experiment, the animals were euthanized in an euthanasia cage (VetTech, UK) with carbon dioxide followed by blood sampling and general autopsy.

A general clinical study of blood samples was performed on an Abacus Junior Vet 2.7 automatic veterinary hematology analyzer (Diatron Messtechnik GmbH, Austria) using Diatron reagent kits. In the blood of animals, 14 indicators were determined: white blood cells (WBC); lymphocytes (LYM); total content of monocytes, eosinophils, basophils and immature cells (MID); granulocytes (GRA); lymphocytes (LY); myelocytes (MI); relative content of granulocytes (GR); erythrocytes (RBC); hemoglobin (HGB); hematocrit (HCT); mean corpuscular volume $(\mathrm{MCV})$; mean corpuscular hemoglobin $(\mathrm{MCH})$; mean corpuscular hemoglobin concentration (MCHC); red cell distribution width (RDWc).

ELISA parameters (immunoglobulin E, histamine) were determined on Immunochem 2100 analyzer (USA) 
2100 (USA) при помощи «сэндвич» - метода, используя наборы видоспецифичных реактивов ELISA (rat).

Содержание, питание, уход за животными, манипуляции, выведение их из эксперимента осуществляли в соответствии с требованиями Приказа МЗ РФ № 267 от 19.06.2003 г. «Об утверждении правил лабораторной практики», требованиями Приказа МЗ СССР № 742 от 13.11.84 г. «Об утверждении правил проведения работ с использованием экспериментальных животных», Международными правилами гуманного обращения с животными - Директива 2010/63/EU Европейского Парламента и Совета Европейского Союза.

Для обработки результатов использовалась программа STATISTICA 10. Результаты представлялись в виде «Взвешенное среднее значение \pm Стандартное отклонение». Статистическая достоверность рассчитывалась с применением однопараметрического ANOVA теста с применением критерия Дункана. Вероятность 0,05 была выбрана в качестве значимого уровня.

\section{Результаты и обсуждение}

Проведенными ранее исследованиями установлено, что наибольшей видоспецифической активностью в отношении изучаемого субстрата (БСА) обладает ферментный препарат грибной протеазы, содержащий комплекс пептидаз и протеиназ, полученный путем направленной ферментации селекционного штамма Aspergillus oryzae с последующей очисткой $[15,16]$. Данный препарат осуществляет гидролиз белковых веществ до аминокислот и пептидов более низкого молекулярного веса [17]. Однако, получаемые после ферментативной обработки продукты обладали низкими органолептическими показателями. С целью улучшения органолептических показателей, а также более полной биотрансформации БСА в мясном сырье, использовали молочнокислые микроорганизмы. Полученные экспериментальные данные фракционного состава белков указывали на отсутствие в исследуемых образцах белковой фракции бычьего сывороточного альбумина [18]. Таким образом, применение двухстадийной обработки мясного сырья позволило снизить аллергенность говядины за счет биотрансформации основного белка аллергена - БСА.

Состояние животных до начала эксперимента находилось в пределах физиологической нормы. Крысы были подвижны и активны; мышцы в тонусе; тактильная реакция сохранена; шерсть плотно прилегает к телу, не взъерошенная, гладкая, чистая, блестящая, кожный покров эластичный, без нарушения целостности; видимые слизистые покровы бледно-розового цвета, истечений и других признаков воспалительных реакций нет. Глаза ярко-красного цвета. Акты мочеиспускания и дефекации находились в пределах нормы. Крысы активно поедали корм, что подтверждает полное потребление предложенных образцов, как в контрольной, так и в опытной группах. Сохранность животных на протяжении эксперимента была $100 \%$. by sandwich method using species-specific (rat) ELISA reagent kits.

Animal management, nutrition, care, manipulations, removal from the experiment were carried out in accordance with the requirements of the Ministry of Health of the Russian Federation Order No. 267 dated 19.06.2003 «On the approval of the laboratory practice rules», the requirements of the Ministry of Health of the USSR Order No. 742 dated 13.11.1984 «On the approval of the rules for work using experimental animals», the International Rules for animal protection - Directive 2010/63/EU of the European Parliament and the Council of the European Union.

STATISTICA 10 software was used to analyze the results. The results were presented as weighted average \pm standard deviation. Statistical significance was calculated using one-way ANOVA test and Duncan test. The probability of 0.05 was chosen as a significant level.

\section{Results and discussion}

Previous studies have shown that the enzyme preparation of fungal protease containing the complex of peptidases and proteases obtained by targeted fermentation with selected strain of Aspergillus oryzae followed by purification possesses the greatest species-specific activity with respect to studied substrate (BSA) $[15,16]$. This preparation hydrolyses protein substances to amino acids and peptides with lower molecular weight [17]. However, the products obtained after enzymatic treatment had low sensory parameters. To improve sensory quality, as well as to obtain more complete biotransformation of BSA in meat raw materials, lactic acid microorganisms were used. The experimental data obtained for the fractional composition of proteins indicated the absence of bovine serum albumin fraction in the samples [18]. Thus, the use of two-stage processing of meat raw materials allowed reducing the allergenic potential of beef due to biotransformation of the main allergenic protein - BSA.

The condition of the animals prior to the experiment beginning was physiologically normal. The rats were mobile and active; muscles were in tonus; tactile response was active; hair tightly adhered to body, not ruffled, smooth, clean, shiny; the skin was elastic, without compromising integrity; visible mucous membranes were pale pink, without efflux and other signs of inflammatory reactions. Eyes were bright red. Urination and defecation were within normal limits. Rats actively ate feed, which confirms full consumption of the proposed samples, both in control and experimental groups. Animal survival throughout the experiment was $100 \%$. 
В течение всего периода наблюдения за животными не было отмечено существенных признаков изменения клинического состояния. Введение в рацион исследуемых образцов не сказывалось на поведении, состоянии кожи, шерстного покрова и видимых слизистых оболочек подопытных животных, также различий в потреблении корма и воды отмечено не было.

Динамика массы тела животных на протяжении эксперимента была положительной. Показано равномерное увеличение массы животных 1-й и 2-й групп в среднем 2-2,6 г/сутки, при этом, интактные крысы 3 группы набирали вес более интенсивно - прирост массы был достоверно выше и составлял 3,3-3,6 г/сутки (рисунок 2).

Максимальные привесы отмечены у интактных животных 3 группы составили 20,2\%, у крыс 2-й группы, потреблявших опытный образец мясных систем $-15,9 \%$, у животных 1-й группы $-14,0 \%$, по отношению к исходной массе животных.

При анализе результатов гематологического исследования крови (таблица 2) крыс 2 группы, потреблявших опытный образец, показано достоверное увеличение лейкоцитов и лимфоцитов до $18 \%$, гранулоцитов (до $35 \%$ ) и моноцитов (до $8 \%, \mathrm{P}>0,05$ ) по сравнению с интактными животными 3-й группы. Стоит отметить, что у животных 1 группы отчмечалось снижение относительного содержания лимфоцитов и моноцитов уменьшилось на $4,9 \%$ и $35,0 \%$, соответственно, при этом выявлено увеличение доли гранулоцитов (до $30 \%)$, по отношению к животным 3 -й группы $(\mathrm{P}<0,05)$.

У крыс 1-й группы наблюдалось достоверное незначительное снижение концентрации гемоглобина (до $4 \%)$, уровня гематокрита и средней концентрации гемоглобина в эритроцитах (до 2\%), при увеличении ширины распределения эритроцитов на 3,6\%, относительно показателей животных 3-й группы. У животных 2-й группы, по сравнению с интактными крысами, отмечено увеличение концентрации гемоглобина, уровня гематокрита и средней концентрации гемоглобина в эритроците свыше $3 \%$. Ширина распределения эритроцитов и средний объем эритроцита у животных 1 и 2 групп превышали значения интактных крыс 3 группы (на 2\%,
During the entire period of observation, there were no significant signs of changes in clinical parameters of the animals. The introduction of the samples into diets did not affect behavior, skin condition, hair and visible mucous membranes of the experimental animals, as well as there were no differences in feed intake and water consumption.

The dynamics of body weight throughout the experiment was positive. A uniform weight gain is shown for the animals in Groups 1 and 2 on the average by $2-2.6 \mathrm{~g} /$ day, while intact rats in Group 3 increased their weight more intensively - the weight gain was significantly higher and accounted for 3.3-3.6 g/day (Figure 2).

The maximum weight gain was observed in the intact animals of Group 3 and accounted for $20.2 \%$; the animals in Group 2 consuming experimental meat products increased their weight by $15.9 \%$, and rats in Group 1 - by $14.0 \%$ compared to initial weight of the animals.

Analysis of hematological test results (Table 2) for the rats in Group 2 consuming experimental feed showed a significant increase in leukocytes and lymphocytes by up to $18 \%$, granulocytes by up to $35 \%$ and monocytes by up to $8 \%(\mathrm{P}>0.05)$ compared to the intact animals in Group 3. In Group 1 there was a decrease in the relative content of lymphocytes and monocytes, $4.9 \%$ and $35.0 \%$ respectively, while the proportion of granulocytes increased (up to $30 \%$ ) in comparison to the animals in Group 3 $(\mathrm{P}<0.05)$.

The rats in Group 1 had an insignificant decrease in the hemoglobin concentration (up to $4 \%$ ), hematocrit and mean corpuscular hemoglobin concentration (by up to $2 \%$ ), with an increase in red cell distribution width by $3.6 \%$ compared to the parameters of animals in Group 3 . The rats in Group 2 had an increase in hemoglobin concentration, hematocrit and mean corpuscular hemoglobin concentration by more than $3 \%$ in comparison with intact rats. The red cell distribution width and mean corpuscular volume in animals of Groups 1 and 2 exceeded the values in

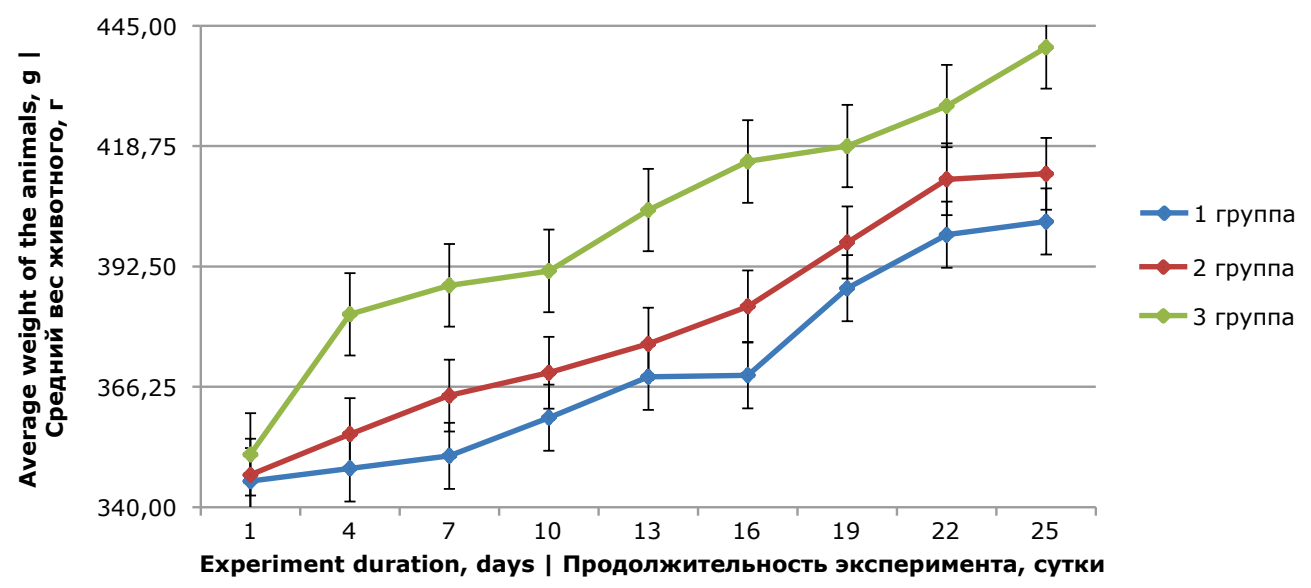

Figure 2. Dynamics in animal weight changes during the experiment

Рис. 2. Динамика изменения массы животных в процессе эксперимента 
$\mathrm{P}<0,05)$. Стоит отметить, что данные показатели животных 1-й группы были максимально приближены к показателям животных 3-й группы (Таблица 2).

Иммуноферментный анализ сыворотки крови крыс показал, что потребление контрольного образца мясных систем животными 1-й группы не приводило к достоверному изменению концентраций иммуноглобулина Е относительно интактных животных 3-й группы. Отмечено, что внесение в рацион животных 2-й группы опытного образца приводило к незначительному увеличению концентрации иммуноглобулина Е на 4,5 \% $(\mathrm{P}<0,05)$ по отношению к животным 1-й группы и на $4,9 \%(\mathrm{P}>0,05)$ по отношению к животным 3-й группы. В отношении гистамина отмечено значительное его увеличение в сыворотке крыс 1-й (на 27\%) и 2-й (до 40\%) групп $(\mathrm{P}<0,05)$, относительно животных 3-й группы. При этом содержание гистамина в сыворотке крови животных 2-й группы было на $11,1 \%(\mathrm{P}<0,05)$ выше относительно показателя животных 1-й группы (Таблица 3).

По результатам аутопсии и макроскопического исследования изучаемых органов животных, различий между группами животными, получавшими разные рационы, не установлено. intact rats of Group 3 (by $2 \%, \mathrm{P}<0.05$ ). It is worth noting that these indicators of the animals in Group 1 were as close as possible to those of the animals in Group 3 (Table 2).

ELISA analysis of rat serum showed that consumption of the control meat products by animals in Group 1 did not mediate a significant change in the immunoglobulin E concentrations compared to the intact animals in Group 3. It was noted that introduction of the experimental meat product into the diet of the animals in Group 2 resulted in an insignificant increase in the immunoglobulin E concentration by $4.5 \%(\mathrm{P}<0.05)$ compared to the intact animals in Group 1 and by $4.9 \%(\mathrm{P}>0,05)$ compared to the intact animals in Group 3. There was a significant histamine increase in rat serum in Group $1(27 \%)$ and in Group 2 (up to $40 \%)(\mathrm{P}<0.05)$ compared to the intact animals in Group 3. While the histamine level in serum of the animals in Group 2 was $11.1 \%(\mathrm{P}<0.05)$ higher compared to the rats in Group 1 (Table 3).

According to the autopsy results and macroscopic study of animal organs, differences between the animal groups receiving different diets have not been established.

Table 2. Hematological analysis of animal blood | Табл. 2. Гематологический анализ крови животных

\begin{tabular}{|c|c|c|c|c|}
\hline Parameters | Показатели & $\begin{array}{l}\text { Normal } \\
\text { values } \\
\text { Hopмa }\end{array}$ & $\begin{array}{c}\text { Group } 1 \\
\text { (control) | } \\
1 \text { группа } \\
\text { (Контрольная) }\end{array}$ & $\begin{array}{c}\text { Group 2 } \\
\text { (experimental) } \\
2 \text { группа } \\
\text { (Опытная) }\end{array}$ & $\begin{array}{c}\text { Group } 3 \\
\text { (intact) | } \\
3 \text { группа } \\
\text { (Интактная) }\end{array}$ \\
\hline | Лейкоциты, 109/л & $6.6-12.6$ & $7.25 \pm 0.52$ & $9.64 \pm 0.53^{\#}$ & $8.18 \pm 0.61$ \\
\hline /L | Лимфоциты, 10 \% /л & $4.78-9.12$ & $5.6 \pm 0.41$ & $7.55 \pm 0.43^{\#}$ & $6.55 \pm 0.46$ \\
\hline
\end{tabular}

Leukocytes, $10 \% / \mathrm{L}$ | Лейкоциты, 10\%/л
Lymphocytes, $10^{9} / \mathrm{L}$ | Лимфоциты, $10^{9} /$ л

\begin{tabular}{|l|l|l|l|}
\hline $0.04-0.39$ & $0.16 \pm 0.03$ & $0.29 \pm 0.05^{\#}$ & $0.27 \pm 0.03$ \\
\hline
\end{tabular}

Total content of monocytes, eosinophils, basophils and эозинофилов, базофилов и незрелых клеток, $10 \%$ /л

\begin{tabular}{|c|c|c|c|c|}
\hline Granulocytes, $10^{9} / \mathrm{L}$ | Гранулоциты, $10^{9} /$ л & $1.00-3.38$ & $1.49 \pm 0.12$ & $1.80 \pm 0.16^{*}$ & $1.33 \pm 0.12$ \\
\hline Lymphocytes, \% | Лимфоциты, \% & $66.6-83.6$ & $77.24 \pm 0.79^{*}$ & $78.29 \pm 1.20^{*}$ & $81.26 \pm 0.87$ \\
\hline Monocytes, \% | Моноциты, \% & $1.0-2.9$ & $2.04 \pm 0.33^{\star}$ & $2.83 \pm 0.42$ & $3.14 \pm 0.28$ \\
\hline $\begin{array}{l}\text { Relative content of granulocytes, \% | Относительное } \\
\text { содержание гранулоцитов, \% }\end{array}$ & $10.0-28$ & $20.73 \pm 0.95^{\star}$ & $18.87 \pm 1.33$ & $16.12 \pm 0.55$ \\
\hline Erythrocytes, $10^{12} / \mathrm{L}$ | Эритроциты, $10^{12} /$ л & $7.07-9.65$ & $8.76 \pm 0.07$ & $8.86 \pm 0.06$ & $8.92 \pm 0.08$ \\
\hline Hemoglobin, g/L | Гемоглобин, г/л & $137-176$ & $149.3 \pm 1.3^{\star}$ & $154.1 \pm 0.9^{\#}$ & $155.2 \pm 1.0$ \\
\hline Hematocrit, \% | Гематокрит, \% & $39.6-52.5$ & $43.67 \pm 0.42^{\star}$ & $45.31 \pm 0.30^{\#}$ & $44.67 \pm 0.33$ \\
\hline Mean corpuscular volume, $\mu \mathrm{m}^{3} \mid$ Ср. объем эритроцита, мкм ${ }^{3}$ & $49-59$ & $49.75 \pm 0.30$ & $51.18 \pm 0.25^{\star \#}$ & $50.10 \pm 0.33$ \\
\hline $\begin{array}{l}\text { Mean corpuscular hemoglobin, pg | Сp. содержание } \\
\text { гемоглобина в эритроците, пг }\end{array}$ & $17.8-20.9$ & $17.05 \pm 0.07^{\star}$ & $17.39 \pm 0.08^{\#}$ & $17.43 \pm 0.11$ \\
\hline $\begin{array}{l}\text { Mean corpuscular hemoglobin concentration, g/L | } \\
\text { Сp. концентрация гемоглобина в эритроцитах, г/л }\end{array}$ & $332-379$ & $342.0 \pm 1.6^{*}$ & $340.0 \pm 1.0^{*}$ & $347.6 \pm 1.3$ \\
\hline $\begin{array}{l}\text { Red cell distribution width, \% | Ширина распределения } \\
\text { эритроцитов, \% }\end{array}$ & $10.5-15.2$ & $16.33 \pm 0.09^{*}$ & $16.04 \pm 0.09^{\star . \#}$ & $15.77 \pm 0.10$ \\
\hline
\end{tabular}

* 一 significant difference from the intact group $(\mathrm{P}<0.05),{ }^{*}$ - significant difference from the control group $(\mathrm{P}<0.05)$

* - достоверное отличие от интактной группы $(\mathrm{P}<0,05)$, , - достоверное отличие от контрольной группы $(\mathrm{P}<0,05)$

Table 3. ELISA results for serum of the animals | Табл. 3. Иммуноферментный анализ сыворотки крови животных

\begin{tabular}{|l|c|c|c|}
\hline Parameters | Показатели & $\begin{array}{c}\text { Group 1 (control) } \\
\text { 1 группа (Контрольная) }\end{array}$ & $\begin{array}{c}\text { Group 2 (experimental) } \\
\text { 2 группа (Опытная) }\end{array}$ & $\begin{array}{c}\text { Group 3 (intact) | } \\
\text { 3 группа (Интактная) }\end{array}$ \\
\hline linl | Гистамин, нг/мл & $70.95 \pm 2.30^{*}$ & $78.85 \pm 2.76^{* \#}$ & $55.79 \pm 1.69$ \\
\hline E, $\mathrm{ng} / \mathrm{ml}$ | Иммуноглобулин Е, нг/мл & $56.87 \pm 1.44$ & $59.42 \pm 1.40$ & $56.65 \pm 1.48$
\end{tabular}

Histamine, ng/ml | Гистамин, нг/мл

Immunoglobulin E, $\mathrm{ng} / \mathrm{ml} \mid$ Иммуноглобулин Е, нг/мл
* - significant difference from the intact group $(\mathrm{P}<0.05),{ }^{*}-$ significant difference from the control group $(\mathrm{P}<0.05)$

Immunoglobulin E, $\mathrm{ng} / \mathrm{ml} \mid$ Иммуноглобулин Е, нг/мл
* - significant difference from the intact group $(\mathrm{P}<0.05),{ }^{*}-$ significant difference from the control group $(\mathrm{P}<0.05)$

$56.65 \pm 1.48$

* - достоверное отличие от интактной группы $(\mathrm{P}<0,05),{ }^{*}$ - достоверное отличие от контрольной группы $(\mathrm{P}<0,05)$ 


\section{Выводы}

Во время эксперимента не было отмечено существенных признаков изменения клинического состояния в опытной группе лабораторных животных. На протяжении всего эксперимента динамика изменения массы тела животных была положительной, при введении опытных образцов в рацион, отмечены меньший прирост веса крыс и меньшие значения привесов животных в конце эксперимента (у крыс 1 группы - 14,0\%, 2 группы - 15,9\%, у животных 3 группы - 20,2\%). Возможно это связано с адаптационными процессами, происходящими в ответ на введение в рацион мясных систем. Это предположение подтверждает то, что крысы 1-й и 2-й групп начиная с 16-х суток увеличивали вес в среднем на 3,4-3,7 г/сутки (достигая ежесуточного прироста интактных крыс 3-й группы).

По результатам общего клинического анализа крови животных, потреблявших опытный продукт, выявлено достоверное изменение концентраций иммунных клеток крови (увеличение лейкоцитов и лимфоцитов до $18 \%$, гранулоцитов до $35 \%$ и моноцитов до $8 \%$ ); увеличение функциональной активности эритроцитов (увеличение концентрации гемоглобина, уровня гематокрита и средней концентрации гемоглобина в эритроците свыше $3 \%$, ширины распределения эритроцитов и среднего объема эритроцита до $2 \%$ ) по сравнению с интактными животными 3-й группы. Соотношение этих данных с анализом иммуноферментных показателей сыворотки крови (гистамин и иммуноглобулин Е) позволяет высказать предположение об экспрессии реагиновых антител (в том числе, IgE, повышающийся у крыс 2 группы до 4,5\%) и взаимодействии на поверхности базофилов и тучных клеток (увеличение числа лейкоцитов за счет лимфоцитов и гранулоцитов), приводящих к дегрануляции и высвобождению гистамина как вазоактивного фактора (увеличение содержания гистамина до 40 \%) [19].

Таким образом, по результатам проведенных исследований можно сделать вывод о том, что мясные модельные системы, полученные с использованием ферментного препарата грибной протеазы и микробиологической стартовой культуры Lactobacillus plantarum, могут вызывать активацию специфических иммунных реакций у лабораторных животных. Возможно, это связано с образованием под действием протеазы большего количества сложноусваеваемых полипептидных и пептидных соединений, вызывающих местные адаптационные реакции [20, 21].

Для более точных сведений о возможных сенсибилизирующих или гипоаллергенных свойствах разрабатываемых модельных мясных систем будут проведены исследования, направленные на анализ протеомного и пептидного состава, биоусвояемости in vitro, с целью выявления антиалиментарных веществ, а также поиском специфических антител к сывороточному альбумину in vivo.

\section{Conclusion}

During the experiment, there were no significant changes in the clinical parameters of the laboratory animals in the experimental group. Throughout the experiment, the dynamics of body weight changes was positive. With the introduction of the experimental products into the diet, a smaller increase in the weight and smaller values of animal weight gain at the end of the experiment were noted (14.0\% for the rats in Group 1, 15.9\% for the rats in Group 2, 20.2\% for the rats in Group 3). This is probably due to the adaptation processes occurring in response to the introduction of meat systems into the diet. This assumption is confirmed by the fact that, starting from the 16th day, the rats in Groups 1 and 2 increased their weight in average by $3.4-3.7 \mathrm{~g} /$ day (reaching daily weight gain of the intact rats in Group 3).

Based on the results of the clinical blood analysis for the animals consuming the experimental product, a significant change in the concentration of immune blood cells was revealed (an increase in leukocytes and lymphocytes by up to $18 \%$, granulocytes by up to $35 \%$ and monocytes by up to $8 \%$ ); an increase in the functional activity of erythrocytes (an increase in hemoglobin concentration, hematocrit and mean corpuscular hemoglobin concentration by more than $3 \%$, the red cell distribution width and mean corpuscular volume by up to $2 \%$ ) compared with the intact animals in Group 3. The correlation of these data with serum ELISA analysis (histamine and immunoglobulin E) allows suggesting the expression of reaginic antibodies (including IgE, increasing in rats of Group 2 by up to $4.5 \%$ ) and interactions on the surface of basophils and mast cells (increase in leukocytes due to lymphocytes and granulocytes) leading to degranulation and release of histamine as a vasoactive factor (an increase in histamine by up to $40 \%$ ) [19].

Thus, based on the results, it can be concluded that model meat systems produced using the enzyme preparation of fungal protease and microbial starter culture of $L a c$ tobacillus plantarum may lead to the activation of specific immune responses in laboratory animals. This is possibly due to protease-mediated formation of a greater amount of indigestible polypeptides and peptides that invoke local adaptation responses [20, 21].

For more accurate information on the possible sensitizing or hypoallergenic properties of the model meat systems being developed, studies will be conducted to analyze the proteomic and peptide composition and bioavailability in vitro, to detect anti-nutritional substances, and to search for specific antibodies to serum albumin in vivo. 


\section{Благодарность}

Авторы статьи выражают благодарность и признательность заведующей Экспериментальной клиникой-лабораторией биологически активных веществ животного происхождения Всероссийского научноисследовательского института мясной промышленности имени В.М. Горбатова Федуловой Л.В., научному сотруднику Котенковой Е.А. и младшему научному сотруднику Василевской Е.P. за разработку дизайна эксперимента in vivo и проведение гематологических и иммуноферментных анализов крови лабораторных животных.

\section{БЛБЛЛОГРАФИЧЕСКИИ СПИСОК}

1. Боровик, Т.Э. Аиетотерапия при пищевой амергии у детей раннего возраста / Т.Э. Боровик, В.А. Ревякина, С.Г. Макарова // Российский амергологический журнал (Приложение № 1). -2005 . - C. 28.

2. Мадодо, К.С. Руководство по лечебному питанию детей. М.: Медицина. - 2000. - С. 384 (142-143).

3. Сажинов, Г.Ю. Обеспечение детского населения России высококачественными продуктами проблема национальной безопасности/ Г.Ю. Сажинов//Вопросы питания, - 1996. № 5. - C. 4-5.

4. J. Bartra, J. Sastre, A. del Cuvillo et al. (2009). From Pollinosis to Digestive Allergy. J Investig Allergol Clin Immunol 2009; Vol. 19, Suppl. 1: 3-10.

5. Restani P., Ballabio C., Tripodi S., Fiocchi A. (2009). Meat allergy. Curr. Opin. Allergy Clin. Immunol. 2009, 9(3), 265-269.

6. Taylor J.S., Erkek E. (2004). Latex allergy: diagnosis and management. Dermatol. Ther. 2004, 17(4). - P. 289-301.

7. L. Terracciano et al. (2002) Use of hydrolysates in the treatment of cow's milk allergy // Ann. Allergy Asthma Immunol. 2002. - Vol. 89, № 1. - P. 86-90.

8. D.J. Hill et al. (1999). The natural history of intolerance to soy and extensively hydrolyzed formula in infants with multiple food protein intolerance (MFPI) // J. Pediatr. - 1999. - Vol. 135. P. 118-121.

9. Borovik, T.E. Experience of dietetic correction of allergy to cow's milk proteins in children of the first year of life / Borovik T.E., Revyakina V.A., Semenova N.N., Yatsyk G.V., Skvortsova V., Makarova S.G. // Questions of children's dietology. - 2005. № 1. - P. 41-47.

10. Von Berg A., Koletzko S., Grubi A. et al. (2003). The effect of hydrolyzed cow's milk formula for allergy prevention in the first year of life: the German infant nutritional intervention study, a randomized, double-blind trial // J. Allergy Clin. Immunol. 2003. - № 11. - P. 533-540.

11. Von Berg A., Koletzko S., Filipiak-Pettrof B. et al. (2008). Preventive effect of hydrolyzed infant formulas persists until age 6 years: long term from the German infant nutritional intervention study (GINI) // J. Allergy Clin. Immunol. 2008. 121 (60). P. $1442-1447$.

12. Ustinova A.V., Timoshenko N.V. Products for baby food based on meat raw materials. Tutorial. - M.: VNIIMP, $-2003,-$ P. 384. 13. Borovik T.E. Organization of healthy diet for children with food allergy. Materials of the VI-th All-Russian Conference "Healthy Nutrition" - M.: 2001. - P. 32-33.

14. Ladodo, K.S. Guidelines for the therapeutic nutrition of children. - M.: Medicine. - 2000, - P. 384 (18-20).

15. Rimareva, L.V. Effective enzyme preparation of proteolytic and hemicellulose action for processing areas of agro-industrial complex / L.V. Rimareva, M.B. Overchenko, E.M. Serba, K.L. Agashicheva // Production of alcohol and alcoholic beverages. - 2010. - № 4. - P. 14-16.

16. Serba, E.M. Effect of detergents on the secretion of intracellular enzymes from the biomass of Aspergillus oryzae fungus / E.M. Serba, M.B. Overchenko, L.V. Rimareva, Y.A. Borscheva // Storage and processing of agricultural raw materials. -2011 . № 12. - P. 39-40.

17. Dydykin, A.S. Hypoallergenic products based on meat for young children / A.S. Dydykin, A.A. Gubina, E.I. Kurbatova // Meat technologies -2015. - № 6. - P. 38-41.

\section{Acknowledgment}

The authors express their gratitude and appreciation to the head of the Experimental Clinic-Laboratory of Biologically Active Substances of Animal Origin of the V.M. Gorbatov All-Russian Meat Research Institute, L.V. Fedulova; research scientist, E. Kotenkova; and junior research scientist, Vasilevskaya E.R. for the development of in vivo experiment design, hematological and ELISA assay of laboratory animal blood.

\section{REFERENCES}

1. Borovik, T.E. Dietotherapy for food allergies in young children / T.E. Borovik, V.A. Revyakina, S.G. Makarova // Russian Allergological Journal (Appendix № 1), -2005, - P. 28.

2. Ladodo, K.S. Guide to the therapeutic nutrition of children M.: Medicine. - 2000. - P. 384 (142-143).

3. Sazhinov, G.Y. Providing the Russian children's population with high-quality products. The problem of national security / G.Y. Sazhinov // Questions of nutrition, - 1996. - № 5, - P. 4-5. 4. J. Bartra, J. Sastre, A. del Cuvillo et al. (2009). From Pollinosis to Digestive Allergy. J Investig Allergol Clin Immunol 2009; Vol. 19, Suppl. 1: 3-10.

5. Restani P., Ballabio C., Tripodi S., Fiocchi A. (2009). Meat allergy. Curr. Opin. Allergy Clin. Immunol. 2009, 9(3), 265-269.

6. Taylor J.S., Erkek E. (2004). Latex allergy: diagnosis and management. Dermatol. Ther. 2004, 17(4). - P. 289-301.

7. L. Terracciano et al. (2002) Use of hydrolysates in the treatment of cow's milk allergy // Ann. Allergy Asthma Immunol. 2002. - Vol. 89, № 1. - P. 86-90.

8. D.J. Hill et al. (1999). The natural history of intolerance to soy and extensively hydrolyzed formula in infants with multiple food protein intolerance (MFPI) // J. Pediatr. - 1999. - Vol. 135. P. 118-121.

9. Borovik, T.E. Experience of dietetic correction of allergy to cow's milk proteins in children of the first year of life / Borovik T.E., Revyakina V.A., Semenova N.N., Yatsyk G.V., Skvortsova V., Makarova S.G. // Questions of children's dietology. - 2005. № 1. - P. 41-47.

10. Von Berg A., Koletzko S., Grubi A. et al. (2003). The effect of hydrolyzed cow's milk formula for allergy prevention in the first year of life: the German infant nutritional intervention study, a randomized, double-blind trial // J. Allergy Clin. Immunol. 2003. - № 11. - P. 533-540.

11. Von Berg A., Koletzko S., Filipiak-Pettrof B. et al. (2008), Preventive effect of hydrolyzed infant formulas persists until age 6 years: long term from the German infant nutritional intervention study (GINI) // J. Allergy Clin. Immunol. 2008. 121 (60). P. 1442-1447.

12. Ustinova A.V., Timoshenko N.V. Products for baby food based on meat raw materials. Tutorial. - M.: VNIIMP, - 2003, - P. 384 13. Borovik T.E. Organization of healthy diet for children with food allergy. Materials of the VI-th All-Russian Conference "Healthy Nutrition" - M.: 2001. - P. 32-33.

14. Ladodo, K.S. Guidelines for the therapeutic nutrition of children. - M.: Medicine. - 2000, - P. 384 (18-20).

15. Rimareva, L.V. Effective enzyme preparation of proteolytic and hemicellulose action for processing areas of agro-industrial complex / L.V. Rimareva, M.B. Overchenko, E.M. Serba, K.L. Agashicheva // Production of alcohol and alcoholic beverages. -2010 . - № 4. - P. 14-16.

16. Serba, E.M. Effect of detergents on the secretion of intracellular enzymes from the biomass of Aspergillus oryzae fungus / E.M. Serba, M.B. Overchenko, L.V. Rimareva, Y.A. Borscheva // Storage and processing of agricultural raw materials. -2011 . № 12. - P. 39-40.

17. Dydykin, A.S. Hypoallergenic products based on meat for young children / A.S. Dydykin, A.A. Gubina, E.I. Kurbatova // Meat technologies -2015. - № 6. - P. 38-41.

18. Dydykin A.S., Gubina A.A., Kurbatova E.I. Selection of enzyme specific for bovine serum albumin in order to create hy- 
18. Dydykin A.S., Gubina A.A., Kurbatova E.I. Selection of enzyme specific for bovine serum albumin in order to create hypoallergenic meat products for baby food // Collection of scientific works of VNIIPBT "Perspective enzyme preparations and biotechnological processes in food and feed technologies". - M., 2014. - P. 159-164. 19. Lisitsyn, A.B. The effect of water with reduced deuterium content on laboratory animals with different functional state of nonspecific defense systems / A.B. Lisitsyn, M.G. Baryshev, A.A. Basov, E.V. Barysheva, I.M. Bykov, A.S. Dydykin, E.E. Tekutskaya, S.S. Dzhimak, L.V. Fedulova // Biophysics, 2014. - Vol. 59. № 4. - P. 757-765.

20. Fedulova L.V., Dzhimak S.S., Kotenkova E.A., Vasilevskaya E.R., Chernukha I.M. (2016). Influence of Deuterium Depleted Water on Rat Physiology: Reproductive Function, Forming and Posterity Development // Journal of Pharmacy and Nutritional Sciences. - № 6. - P. 55-60. DOI: http://dx.doi. org/10.6000/1927-5951.2016.06.02.3.

21. Vasilevskaya E.R., Kotenkova E.A., Fedulova L.V. (2016). The study of tissue-specific proteins and peptides influence on innate immunity // J Clin Cell Immunol. V. 7:3(Suppl). - P. 86. - http:// dx.doi.org/10.4172/2155-9899.C1.028 DOI: 10.4172/21559899.C1.028.

\section{СВЕДЕНИЯ ОБ АВТОРАХ}

Принадлежность к организации

Дыдыкин Андрей Сергеевич - кандидат технических наук, доцент, руководитель отдела научно-прикладных и технологических разработок. Всероссийский научно-исследовательский институт мясной промышленности имени В.М. Горбатова

109316, г. Москва, ул. Талалихина, д. 26

Тел.: 8-495-676-75-41

E-mail:das_tih@mail.ru

Минаев Михаил Юрьевич - кандидат технических наук, руководитель ПЦР направления, Всероссийский научно-исследовательский институт мясной промышленности имени В.М. Горбатова

109316, г. Москва, ул. Талалихина, д. 26

Тел.: 8-495-676-60-11

E-mail: mminaev@inbox.ru

Толмачева Галина Сергеевна - аспирант, Всероссийский научно-исследовательский институт мясной промышленности имени В.М. Горбатова

109316, г. Москва, ул. Талалихина, 26

Телефон: раб. 8-495-676-92-11

E-mail: vivarium@vniimp.ru

Мусатова Анастасия Андреевна - аспирант, Всероссийский научно-исследовательский институт мясной промышленности имени В.М. Горбатова

109316, г. Москва, ул. Талалихина, д. 26

Тел.: 8-495-676-75-41

E-mail: asya_anastasia@mail.ru

\section{Критерии авторства}

Авторы в равных долях имеют отношение к написанию рукописи и одинаково несут ответственность за плагиат.

Ответственность за работу и предоставленные сведения несут все авторы.

Все авторы в равной степени участвовали в этой работе:

Дыдыкин А.С. разработал технологию изготовления модельных мясных систем;

Минаев М.Ю. обосновал использование стартовой культуры Lactobacillus plantarum и обеспечил ее подготовку и внесение в модельные мясные системы;

Толмачева Г.С. осуществляла контроль за содержанием лабораторных животных в течение всего эксперимента и произвела статистическую обработку результатов;

Мусатова А.А. осуществляла технологическую выработку модельных мясных систем.

Обобщение материалов и редактирование статьи в соответствии с требованиями журнала произвел Дыдыкин А.С.

Конфликт интересов

Авторы заявляют об отсутствии конфликта интересов.

Поступила 27.02.2017 poallergenic meat products for baby food // Collection of scientific works of VNIIPBT "Perspective enzyme preparations and biotechnological processes in food and feed technologies". M., 2014. - P. 159-164.

19. Lisitsyn, A.B. The effect of water with reduced deuterium content on laboratory animals with different functional state of nonspecific defense systems / A.B. Lisitsyn, M.G. Baryshev, A.A. Basov, E.V. Barysheva, I.M. Bykov, A.S. Dydykin, E.E. Tekutskaya, S.S. Dzhimak, L.V. Fedulova // Biophysics, 2014. - Vol. 59. № 4. - P. 757-765.

20. Fedulova L.V., Dzhimak S.S., Kotenkova E.A., Vasilevskaya E.R., Chernukha I.M. (2016). Influence of Deuterium Depleted Water on Rat Physiology: Reproductive Function, Forming and Posterity Development // Journal of Pharmacy and Nutritional Sciences. - № 6. - P. 55-60. DOl: http://dx.doi. org/10.6000/1927-5951.2016.06.02.3.

21. Vasilevskaya E.R., Kotenkova E.A., Fedulova L.V. (2016). The study of tissue-specific proteins and peptides influence on innate immunity // J Clin Cell Immunol. V. 7:3(Suppl). - P. 86. - http:// dx.doi.org/10.4172/2155-9899.C1.028 DOI: 10.4172/21559899.C1.028.

\section{AUTHOR INFORMATION} Affiliation

Dydykin Andrei Sergeevich - candidate of technical sciences, docent, head of the Department of Scientific Applied and Technological Developments, The V.M. Gorbatov All-Russian Meat Research Institute,

109316, Moscow, Talalikhina str., 26

Tel: 8-495-676-75-41

E-mail: das_tih@mail.ru

Minaev Mikhail Yurievich - candidate of technical sciences, head of the Molecular Diagnostic Division, The V.M. Gorbatov All-Russian Meat Research Institute,

109316, Moscow, Talalikhina str., 26

Tel: 8-495-676-60-11

E-mail: mminaev@inbox.ru

Tolmacheva Galina Sergeevna - postgraduate student, The V.M. Gorbatov All-Russian Meat Research Institute

109316, Moscow, Talalikhina str., 26

Tel: 8-495-676-92-11

E-mail: vivarium@vniimp.ru

Musatova Anastasija Andreevna - postgraduate student, The V.M. Gorbatov All-Russian Meat Research Institute,

109316, Moscow, Talalikhina str., 26

Tel: 8-495-676-75-41

E-mail: asya_anastasia@mail.ru

\section{Contribution}

Authors equally contributed to the writing of the manuscript and are equally responsible for plagiarism.

All authors are responsible for the work and information provided.

All authors equally participated in this work.

Dydykin A.S. has developed the manufacturing technology of the model meat systems;

Minaev M.Y. substantiated the use of starter culture of Lactobacillus plantarum and provided for its preparation and introduction into model meat system;

Tolmacheva G.S. supervised the care of laboratory animals throughout the experiment and performed statistical processing of the results;

Musatova A. carried out the technological production of model meat systems;

Synthesis and editing of the article in accordance with the requirements of the journal were carried out by Dydykin A.S.

Conflict of interest

The authors declare no conflict of interest.

Received 27.02.2017 